\title{
Correlation Analysis of Landscape Patterns with Surface Water Quality in Yancheng Coastal Wetland, Jiangsu, China
}

\author{
Peng Tian', Jialin Li ${ }^{1,2,3 *}$, Luodan Cao ${ }^{1 * *}$, Ruiliang Pu${ }^{4}$, Hongbo Gong ${ }^{5}$ \\ ${ }^{1}$ Department of Geography and Spatial Information Techniques, Ningbo University, Ningbo 315211, China \\ ${ }^{2}$ Institute of East China Sea, Ningbo University, Ningbo 315211, China \\ ${ }^{3}$ Ningbo Universities Collaborative Innovation Center for land and Marine Spatial Utilization \\ and Governance Research at Ningbo University, Ningbo 315211, China \\ ${ }^{4}$ School of Geosciences, University of South Florida, Tampa, FL 33620-5250, USA \\ ${ }^{5}$ School of Law, Ningbo University, Ningbo 315211, China
}

Received: 12 August 2020

Accepted: 25 January 2021

\begin{abstract}
Quantitatively exploring a relationship between coastal wetland landscape pattern and water quality (WQ) is conducive to providing scientific guidance for the improvement of regional WQ, the prevention of water pollution, and the formulation of regional landscape protection and planning. With the 2019 landscape data and WQ sampling data from the Yancheng Coastal Wetland, five-level WQ sampling points at different scales were established. By applying ecological and statistical analysis methods, correlations between the landscape patterns and WQ indicators in different buffer zones were analyzed. Analysis results showed that: (1) The area of aquafarm, farmland and dry ponds were widely distributed at different scales, and the landscape level index and type level index in different buffer zones were significantly different. (2) There were significant correlations between coastal wetland landscape types and WQ indicators. Total nitrogen, total phosphorus, ammonia nitrogen $\left(\mathrm{NH}_{4}^{+}-\mathrm{N}\right)$, WQ indicators showed significant positive correlations with farmland landscapes in $0.5 \mathrm{~km}, 1 \mathrm{~km}, 2 \mathrm{~km}$, and $2.5 \mathrm{~km}$ buffer zones, and significant negative correlations with tidal flats in $0.5 \mathrm{~km}-2.5 \mathrm{~km}$ buffer zones. The Chemical Oxygen Demand index was significantly correlated with various landscapes in the area. (3) At the landscape level, the landscape level index, which represents the fragmentation and complexity of coastal wetland landscapes, had a significant correlation with water pollution indicators, such as mean patch areas, fractal dimension, landscape shape index, plaque cohesion, contagion index and other indexes. At the level of landscape class, farmland, aquafarm, dry ponds, construction land in artificial
\end{abstract}

*e-mail: nbnj2001@163.com

**e-mail: aidushude@163.com 
wetlands, and various types of level indexes of Suaeda salsa, Phragmites communis, and Spartina alterniflora in natural wetlands were highly correlated with WQ indicators.

Keywords: landscape pattern, water quality, redundancy analysis, coastal wetland, Yancheng

\section{Introduction}

Water resources are a basis of human survival and social development. Water quality (WQ) plays a key role in public health, environmental protection, and agricultural development, and water chemistry characteristics reflect a WQ situation to a certain extent [1]. A landscape pattern is comprehensively formed under natural conditions of regional topography, climate, soil, WQ and human activities [2, 3]. Changes in the landscape pattern will affect a series of ecological factors, such as regional surface runoff, soil conditions, various biogeochemical and physical cycles [4]. Hydrological processes change the concentration of pollutants entering rivers and lakes, and profoundly affect regional hydrochemical characteristics [5, 6]. Therefore, in order to strengthen the rational use and effective protection of regional water resources, it is necessary to quantify and analyze relationships between landscape patterns and regional WQ and to better understand regional ecological processes.

Since the 1970s, research on the impact of landscape patterns on surface WQ has been widely carried out and has received continuous attention from experts and scholars at home and abroad [7, 8]. A relatively complete theoretical method system has been formed by many relationship studies between landscape patterns and surface WQ [9, 10]. Early research focused on analyzing the impact of different land cover types on WQ conditions in a river basin [11, 12]. Irrational land use exacerbated a transfer of nutrients to water bodies [13]. Intense agricultural activity and rapid urbanization have severely accelerated the deterioration of WQ [14]. Intensive and extensive farming, especially the use of fertilizers, has a greater impact on WQ [15]. Chemical fertilizers enter surface water through runoff, which lead to a significant positive correlation between agricultural land coverage and water pollution. Due to urbalization, an increase in roads, houses, and parking lots leads to an increase in runoff, which in turn provides a new way for the transport of pollutants to rivers [16]. Based on geographic information system (GIS) technology and landscape ecology, landscape indicators have become an effective means to quantify land use/cover allocation [17]. A landscape index reflects a number, distribution, structure, and function of types of land cover in a region. The index is more sensitive to changes in natural and human activities in the region, and it is more direct to analyze a degree of water pollution in the region [18]. Wang and Zhang research found that there is a significant relationship between WQ index and landscape pattern index [18]. Wijesiri et al. believe that land use changes directly affect the
WQ of the basin [19]. Many studies indicate that a regional WQ is a comprehensive reflection of multiscale environmental factors, but changes in regional land use/cover-landscape patterns are considered to be a main reason affecting regional water environmental quality [20,21]. Because WQ is affected by a variety of natural and human factors, including rainfall, soil types, geology, topography, urbanization, and industrial and agricultural activities, these factors can be considered as larger-scale land use/cover-landscapes patterns of the pattern process [22]. Therefore, the landscape patterns in a region can affect the ecological function of the region, the discharge of pollutants into the river, and the regional WQ security.

An investigation on a relationship between landscape pattern and WQ at different scales has focused on the relationship between landscape and ecological process [22-24]. Well-established buffer zones at different scales with WQ sampling points as a center is the main research method of the relationship between landscape pattern and WQ at present, and the impact of landscape pattern on WQ in different scale buffer zones is explored [25]. For example, Liberoff et al. found that different landscapes have different influence radius on WQ content. The landscape influence radius of Soluble Reactive Phosphorous (SRP) (100-180 km) is larger than that of Total Phosphorous (TP) $(10-25 \mathrm{~km})$ [26]. Zhou established 200, 600 and $1000 \mathrm{~m}$ buffer areas to analyze the relationship between landscape pattern and WQ characteristics [27]. Generally, some common physical and chemical indexes of WQ include potential of hydrogen $(\mathrm{pH})$, suspended solids (SS), chemical oxygen demand (COD), biochemical oxygen demand (BOD), total nitrogen (TN), total phosphorus (TP), total dissloved solids (TDS) etc. [26, 27]. Most of studies take rivers, reservoirs, lakes, and cities as their research areas, and, currently, a research interest on WQ of an ecological protection area is increasing [7, 27-29]. However, the research on WQ and landscape pattern of coastal wetlands is relatively blank. It is also a new attempt and innovation to compare a correlation analysis between landscape pattern and river WQ to that between a landscape pattern and the WQ of coastal wetlands. In this study, we also focused on an analysis of the relationship between landscape pattern and WQ from a perspective of landscape level, while studies coupled with regional landscape type, landscape level and landscape type level are relatively rare [30, 31]. In order to improve the level of regional water resource management and to promote the sustainable development of regional ecological environment, multidirectional and multi angle practical research is needed to enrich the quantitative analysis of the relationship 
between landscape pattern and regional WQ and environmental conditions at different scales.

In 2019, the Yancheng coastal wetland was listed as a World Natural Heritage. The Yancheng coastal wetland is extremely rich in biodiversity. It is a typical and representative internationally important coastal wetland ecosystem, and it is also an important resting place and wintering place for migratory waterfowl in the world. The change of a certain element of the Yancheng coastal wetland ecosystem has an important impact on the regional and even global ecosystems. Water resources are an important part of the coastal wetland ecological environment. The health of WQ is of vital importance to the Yancheng coastal wetland with rich biodiversity. At present, given the various pressures from reclamation of tidal flats, construction of road traffic infrastructure, and continuous expansion of aquafarms and dry ponds in the wetland, regional WQ conditions are gradually deteriorating [32, 33]. This study chooses the Yancheng coastal wetland as a research area, used multi-season WQ sampling data and 2019 landscape type data as basic information sources, and applied spatial analysis and statistical analysis methods to establish five levels of buffer zones at different scales, from landscape types, landscape levels and types level. The horizontal analysis of correlation characteristics between landscape patterns and WQ indicators at different scales in the wetland. In this study, we mainly explored the following issues: 1) the influence of different land use types-landscape on river WQ was assessed; 2) under different scales, the influence degree and difference of landscape indexes on WQ were analyzed from landscape levels and class level indexes; 3) the main landscape indexes affecting the
WQ of the wetland were explored and corresponding solutions were proposed. Given a view of accumulating data and experience on the analysis of the relationship between coastal wetland landscape pattern and WQ in a coastal zone, the analysis results and extracted findings will provide a planning basis for the optimization of the coastal wetland landscape pattern and the rational layout of land use based on requirements of water environmental protection.

\section{Materials and Methods}

\section{Study Area}

The Yancheng coastal wetland lies in the middle coastal region of Jiangsu Province $\left(32^{\circ} 34^{\prime}-34^{\circ} 28^{\prime} \mathrm{N}\right.$, $119^{\circ} 48^{\prime}-120^{\circ} 56^{\prime} \mathrm{E}$ ) (Fig. 1). It is mainly formed by collaborative effects of waves and tides in the Yellow Sea and the East China Sea as well as deposition of sediments in the Yellow River Delta and Yangtze River Delta. It belongs to a silt coast. The study area is located in the transition zone from the northern subtropical zone to the warm temperate zone of China. It has obvious monsoon characteristics and is greatly affected by the ocean. The annual precipitation and annual average temperature are about $1030 \mathrm{~mm}$ and $15.5^{\circ} \mathrm{C}$, respectively. The four seasons are distinct, the rainfall is abundant, and the precipitation is mainly concentrated from June to September. This study selected the Yancheng coastal wetland according to following principles: main roads and rivers in Yancheng were chosen as the land boundary of the study area, while the maximum landscape coverage which is extended slightly toward
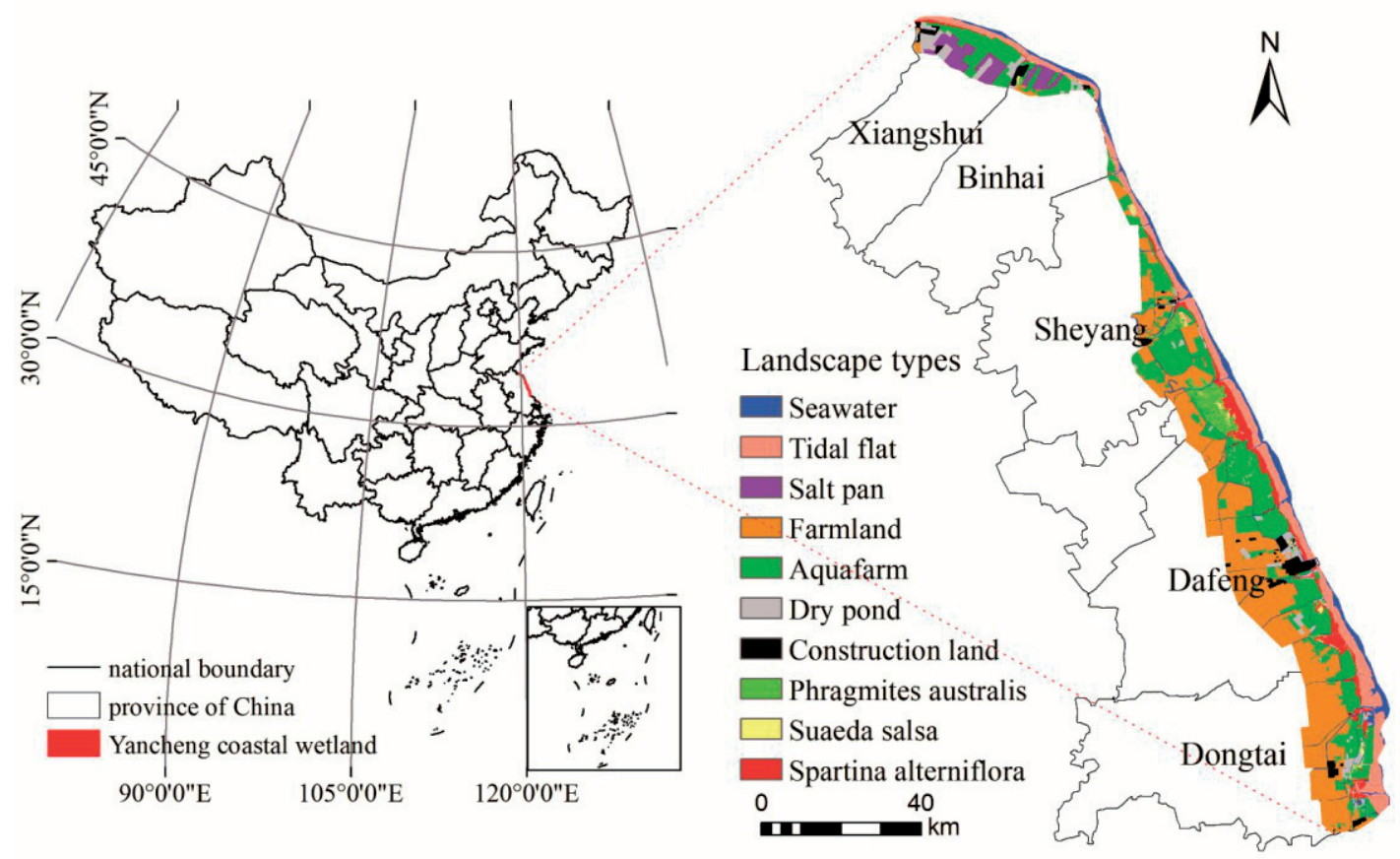

Fig. 1. Geographic location of the study area. 
the sea area on images of coastal wetland was used as the sea boundary. The study area is bordered with Guan River that is next to the administrative boundary in the south region of Yancheng [34].

\section{Data Sources and Pre-Processing}

\section{Landscape Data}

Landsat TM/OLI image data used in this study were downloaded from the website of United States Geological Survey (USGS) (http://glovis.usgs.gov/). Spatial resolution of Landsat TM/OLI image data was $30 \mathrm{~m}$. Images in 2019 were collected and the satellite orbit number was path 119/row 37 and 120/36. Through interpretation remote sensing data and field survey, the landscape type distribution patterns in the study area were mapped. Accuracy of all landscape types was verified and reached $>85 \%$. Considering practical situation of landscape distribution in Yancheng City and research demands, landscape types in the study area were divided into natural wetland and artificial wetland. The natural wetland covers seawater, tidal flat, Phragmites australis, Suaeda salsa and Spartina alterniflora. The artificial wetland includes salt pan, farmland, aquafarm, dry pond and construction land [34].

\section{Water Quality Sample Data}

In the middle of November 2018, late February 2019, mid-May, and early August, a one-week field sampling survey was conducted on the Yancheng coastal wetland. The first sampling determined the geographic coordinates of the sampling location, and then repeated the sampling three times. In view of the short sampling time span and avoiding the seasonal influence of sampling water quality, the average value of four samplings is used for analysis. A total of 64 samples of Yancheng coastal wetland water quality were collected in each phase (Fig. 2).

Based on the interpretation of the land use types interpreted by the remote sensing image and the on-site survey, the adoption zone and the sampling point are determined, and 11 sample zones are set perpendicularly to the coastal zone from north to south. According to the different types of land on each sample zone, different points are set for sampling. In the process of setting sample points, try to ensure that the sample points are evenly distributed in each buffer zone. The number of sampling points in each buffer zone is equal to or greater than 1 , and the distance of sampling points in different buffer zones is greater than $0.5 \mathrm{~km}$. The determination of sampling points is determined by the diversity of land use types in the buffer zone.

The determination of sampling points was based on the principle of "consistency of the underlying surface and representativeness of the sampling points" [35]. At each sampling point, a surface $(0.5 \mathrm{~m})$ water sample was collected separately in a pre-treated white polyethylene plastic bottle, and the sampling point environment was recorded at the same time. With reference to surface water environmental quality standards (GB3838-2002), the WQ measurement indicators of the sample mainly

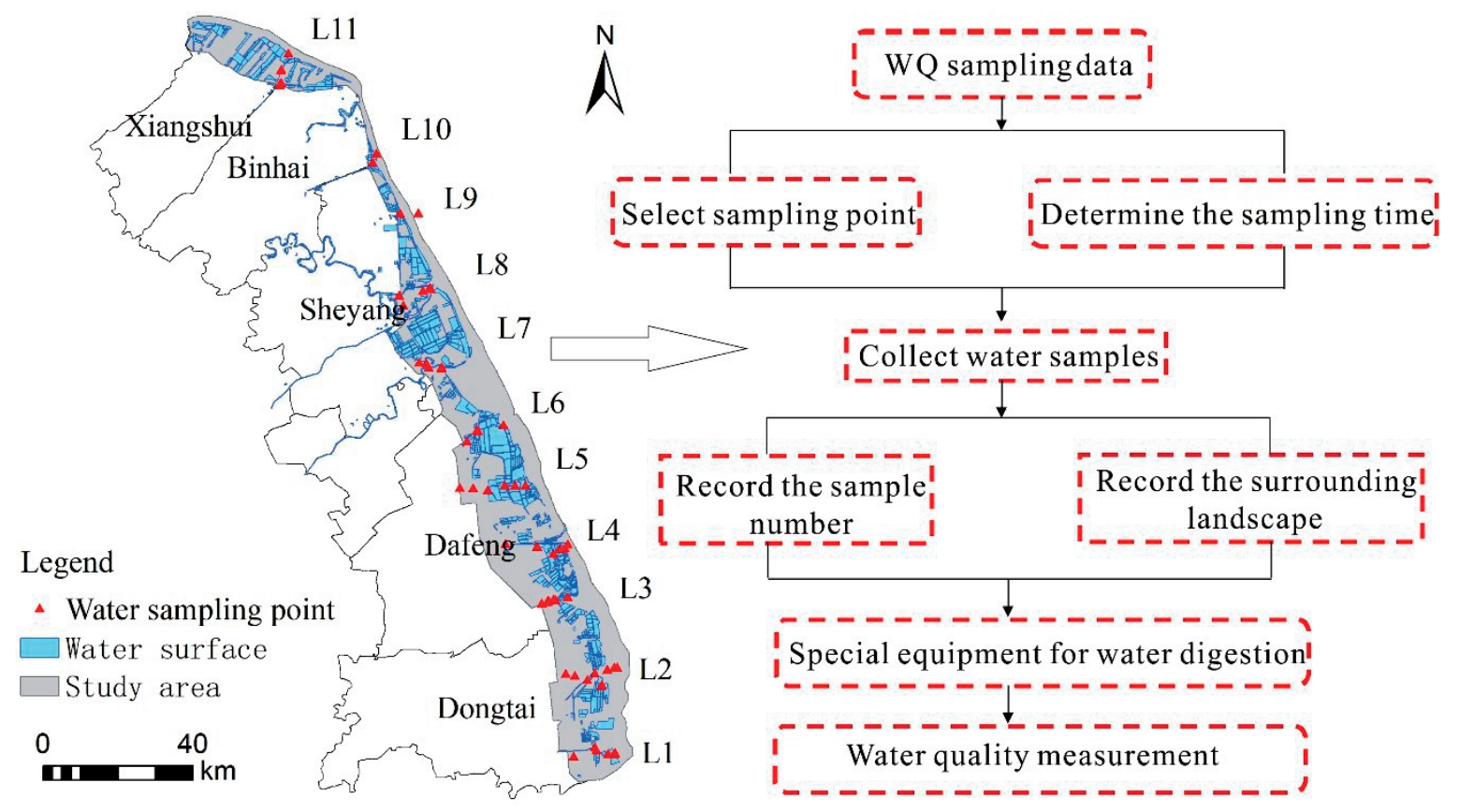

Fig. 2. Landscape types and distribution of sampling points in the study area.

Note: From the south to north, sampling lines were Xinchuang Port Line (L1), Liangduo River Line (L2), Chuandong Port Line (L3), Wang Port Line (L4), Wanzhuang Port Line (L5), Doulong Port Line (L6), Xinyang Port Line (L7), Sheyang River Line (L8), Shuangyang Port Line (L9), Biandan Port Line (L10) and Xinhuan River Line (L11). 
include total phosphorus (TP), total nitrogen (TN), ammonia nitrogen $\left(\mathrm{NH}_{4}^{+}-\mathrm{N}\right)$, and chemical oxygen demand (COD). Per the method of index measurement, the national standard water quality monitoring and analysis method was adopted [36]. The collected water samples were boxed and stored in a refrigerated method to slow down the speed of physical and chemical effects. The samples were transported back to a laboratory for processing and analysis as soon as possible. The experiment approach used 1 control, 3 parallel, and measured values of each indicator $[36,37]$.

\section{Research Methods}

\section{Extraction of Buffer Zones and Selection of Landscape Indexes}

Correlation characteristics between landscape types and water quality (WQ) at different sampling points in the study area at different scales were quantified and analyzed by using buffer zones. Five-level buffer zones centered at sampling points were constructed with references to previous studies and practical situations of Yancheng coastal wetland [38]. Sizes of these buffer zones were $0.5 \mathrm{~km}, 1 \mathrm{~km}$, $1.5 \mathrm{~km}, 2 \mathrm{~km}$ and $2.5 \mathrm{~km}$, respectively. Since landscape types in the Yancheng coastal wetland change slightly at a small scale, the buffer zone was divided at the scale of $500 \mathrm{~m}$.

As a quantitative research method which is commonly used in landscape ecology, the landscape pattern index can condense basic information of landscape pattern in a region, and it has been widely used in studies of landscape pattern in the region [39]. Hence, in this study, four class-level indexes were chosen, which were percentage of landscape type (Pland), plaque density (PD), largest patch index (LPI), edge density (ED) and aggregation index (AI). Pland reflects landscape components and it calculates the relative proportion of a plaque type in the whole landscape area. It is one of references to determine the dominant landscape elements in a landscape. PD and ED represent fragmentation of landscape pattern in a region. The higher fragmentation brings the stronger landscape heterogeneity and the higher risk of water pollution in the region. AI reflects plaque aggregation in landscapes. Another 12 landscape-level indexes were chosen, to distinguish the two indexes, "c" is added in front of the landscape class level index, mainly including coverage area (cCA), largest plaque index (cLPI), edge density (cED), mean patch areas (cMPS), fractal dimension (cFRAC), number of plaques (cNP), plaque density (cPD), aggregation index (cAI), contagion index (cCONTAG), landscape shape index (cLSI), plaque cohesion (COHESION), intersperse juxtaposition index (cIJI), and Shannon diversity index (cSHDI). Landscape indexes were calculated from the software Fragstats 4.2. Relevant definitions and meanings of the landscape indexes are introduced in [34].

\section{Data Statistics and Basic Processing}

The landscape index data in different buffers obtained by statistics were plotted using Origin 2017 software. As a direct gradient sequencing analysis method, redundancy analysis can disclose a relationship between species factors and multi-group variables of environmental factors in a region through statistical analysis [40]. Existing studies mainly implemented redundancy analysis based on CANOCO for Windows to interpret the relationship between landscape pattern and multi-variable characteristics of WQ in a wetland environment [27, 41]. Firstly, Detrended Correspondence Analysis (DCA) of sampling indexes was performed with CANOCO 4.5 software [27]. If the numerical value of the first axis of the lengths of gradient is higher than 4.0, Canonical Correspondence Analysis (CCA) shall be chosen. If the numerical value ranges within 3.0 4.0, either RDA or CCA can be chosen. If the numerical value is smaller than 3.0, Redundancy Analysis (RDA) is better than CCA. According to DCA results of WQ indexes at different sampling points, the numerical values of the first axis were 0.089 and $0.002(<3.0)$. Therefore, RDA method was applied in the present study.

\section{Results and Discussion}

\section{Landscape Pattern Analysis in Different Buffer Zones \\ Land Use/Land Cover Description Analysis in Different Buffer Zones}

The WQ sampling points are often used as research objects to analyze the landscape pattern in buffer zones at different scales. A five-level buffer was generated with centered at sampling points of the WQ in the study, and the land use/land cover (LULC) conditions (Fig. 3) in the buffer zones at various levels were obtained by superimposing the wetland landscape map over the buffer zones. Given the large number of samples, the analysis was based on 11 sampling lines.

In the buffer zones of $0.5 \mathrm{~km}-2.5 \mathrm{~km}$, except for Shuangyang port and Biandan port, which were dominated by tidal flat and aquafarm, the LULC types were dominated by farmland, aquafarm and dry pond. When the buffer zone width increased from $0.5 \mathrm{~km}$ to $2.5 \mathrm{~km}$, the area of constructed wetland tended to increase, while the area of Phragmites australis and Suaeda salsa in natural wetland tended to decrease. By comparing distributions of LULC types in the buffer zones, the farmland and fishpond were the main LULC types in the coastal wetlands, and human activities had a strong impact on the coastal wetlands. 

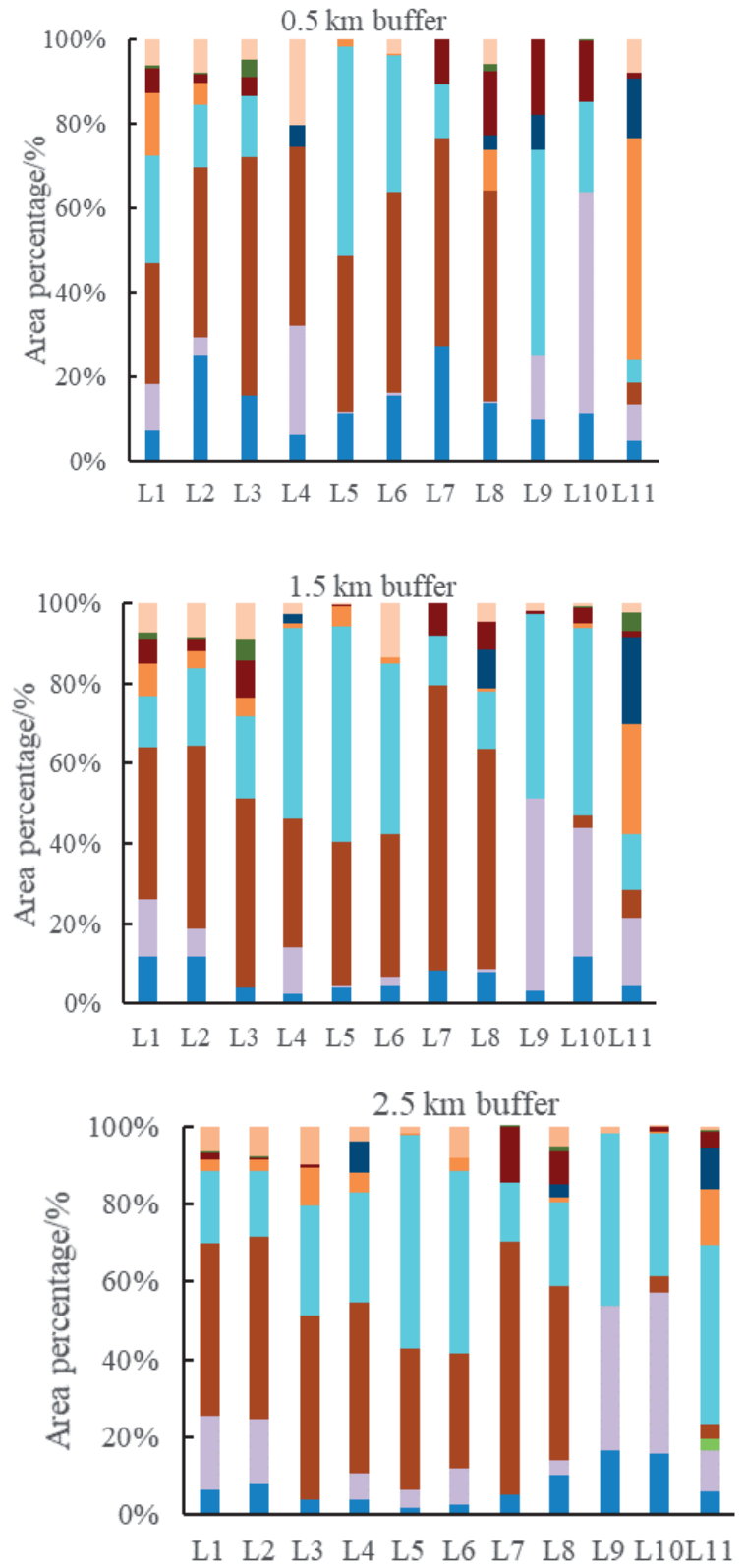
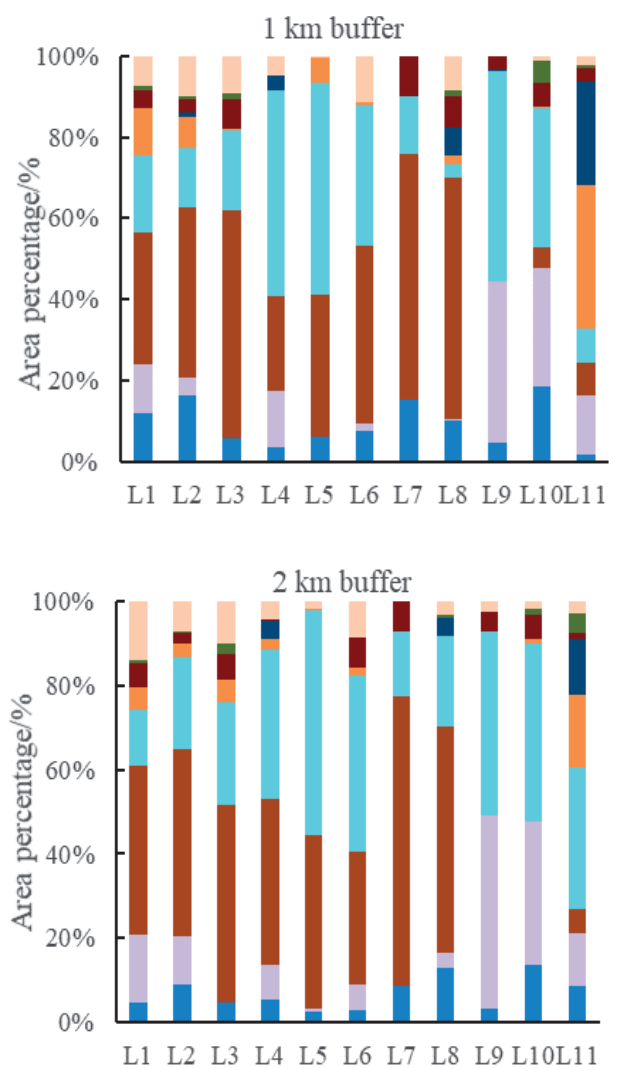

- Spartina alterniflora

- Suaeda sal sa

- Phragmites australis

- Construction land

Dry pond

- Aquafarm

- Farmland

- Salt pan

- Tidal flat

- Seawater

Fig. 3. Percentages of LULC types in buffer zones at all levels.

\section{Landscape Level Indexes in Different Buffer Zones}

Landscape level indexes in different buffer zones are denoted by box plots (Fig. 4). NP, PD and MPS all can reflect a degree of landscape fragmentation in a region. The maximum NP lied in the $1 \mathrm{~km}$ and $1.5 \mathrm{~km}$ buffer zones, while the minimum NP was in the $0.5 \mathrm{~km}$ buffer zone. Median, upper quartile and lower quartile had an equilibrium distribution in $1 \mathrm{~km}-2.5 \mathrm{~km}$ buffer zones, but there's an abnormal distribution in the $0.5 \mathrm{~km}$ buffer zone. NP has more outliers in the $0.5 \mathrm{~km}-2 \mathrm{~km}$ buffer. Maximum, minimum, median, the upper quartile and lower quartile of PD declined with widening buffer zones, but MPS showed the opposite, indicating that landscape fragmentation close to sampling points decreased from the center to their peripheral regions. As a boundary density of different plaques, the maximum and median of ED were in the $0.5 \mathrm{~km}$ buffer zone, and the maximum of ED was negatively correlated with width of the buffer zone. It is indicated that there's obvious material energy exchange in the $0.5 \mathrm{~km}$ buffer zone, and landscape in the region tended to be fragmented. Value of LPI can reflect intensity of human activities in a region. The maximum of LPI was in the $0.5 \mathrm{~km}$ buffer zone, while the maximum median was in the $1.5 \mathrm{~km}$ buffer zone. Boxes of upper quartile and lower quartile were relatively long in the $1.5 \mathrm{~km}$ buffer zone, indicating the frequent human activities in the $1.5 \mathrm{~km}$ buffer zone. LSI reflects morphological complexity of landscape plaque. The more fragmented the landscape, the more complicated morphology will be. LSI in the $0.5 \mathrm{~km}$ buffer zone changed slightly, but it changed 

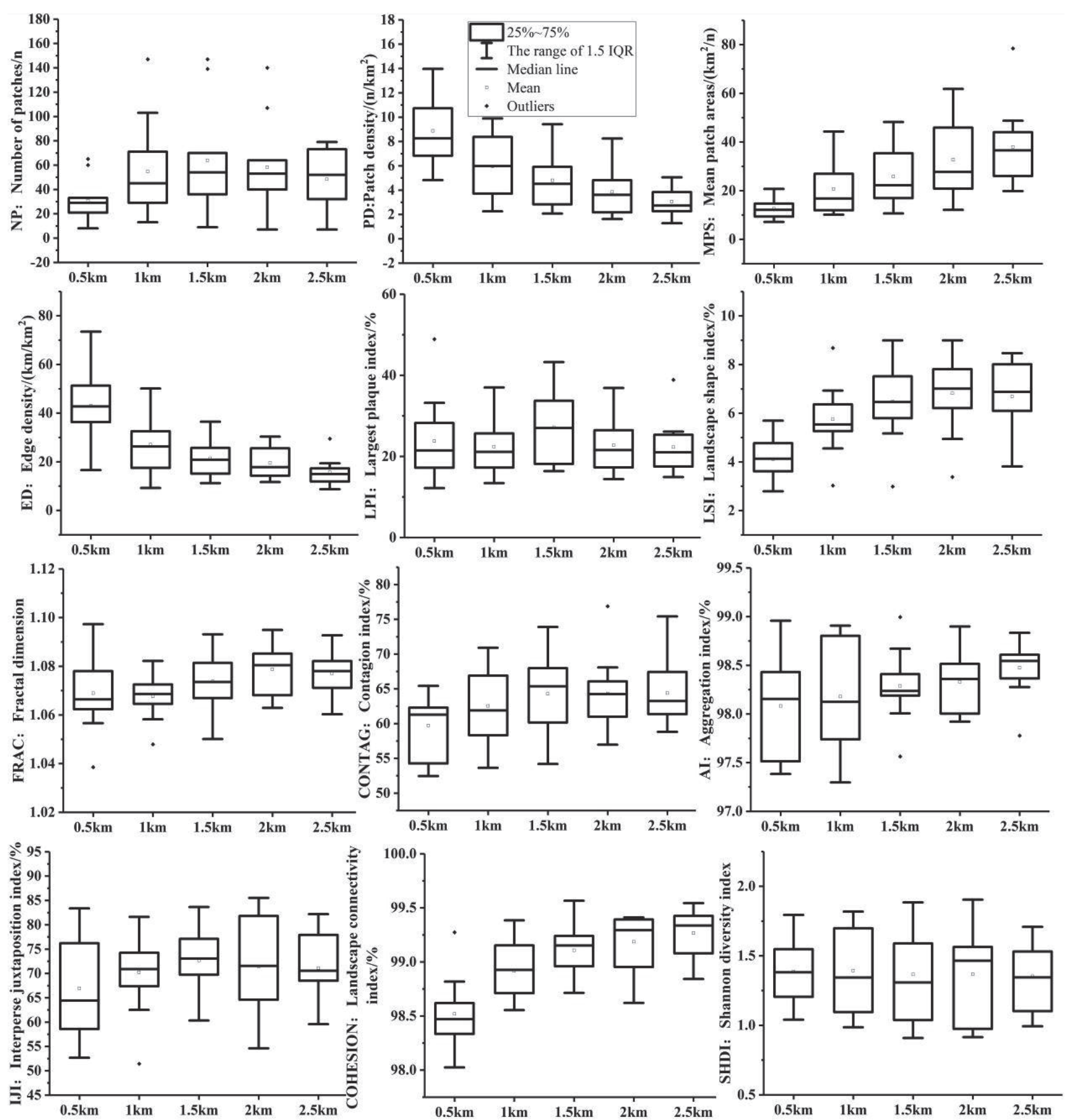

Fig. 4. Landscape level indices in different buffer zones.

Note: IQR is Inter-Quartile Range

greatly in the $1 \mathrm{~km}-2 \mathrm{~km}$ buffer zones and it was very sensitive to external interferences.

For landscapes with great external interfaces, FRAC is close to 1 . The maximum and minimum of FRAC were in the $0.5 \mathrm{~km}$ buffer zone. FRAC value in the $1 \mathrm{~km}-1.5 \mathrm{~km}$ buffer zones was relatively small. The third fractal dimension in the $0.5 \mathrm{~km}-1.5 \mathrm{~km}$ buffer zones had a small gap and it was close to 1 , indicating that the human activities in the $1.5 \mathrm{~km}$ buffer zone had great impacts. Both CONTAG and AI reflect an aggregation degree of landscape in a region. With increasing width of a buffer zone, the aggregation degree of landscape increases. The plaque aggregation degree in landscapes in the $0.5 \mathrm{~km}-2 \mathrm{~km}$ buffer zones was increased accordingly, which also reflected the poor landscape aggregation in the buffer zones close to sampling points and the increasing trend of landscape fragmentation. IJI reflects separation degree of landscape by comparing numbers of adjacent landscape types. The maximum of IJI showed a small gap in five-level buffer zones and there's a relatively uniform separation degree. However, there's a large median of IJI in the $1 \mathrm{~km}-2 \mathrm{~km}$ buffer zones, which reflected the relatively outstanding landscape separation in these buffer zones. COHESION 
can measure landscape connectivity in a region effectively. The maximum of COHESION was in the $1.5 \mathrm{~km}$ buffer zone, and the median of COHESION in $2 \mathrm{~km}-2.5 \mathrm{~km}$ buffer zones was relatively high. On contrary, the landscape connectivity in the $0.5 \mathrm{~km}$ buffer zone was the poorest, manifested by the lowest minimum and median of COHESION. SHDI reflects landscape heterogeneity and it is extremely sensitive to the non-equilibrium distribution layout of plaques. The maximum of SHDI was relatively equilibrium in the $0.5 \mathrm{~km}-2.5 \mathrm{~km}$ buffer zones. The maximum median was in the $2 \mathrm{~km}$ buffer zone and the upper quartile was in the $1 \mathrm{~km}$ buffer zone, which proved the relatively outstanding landscape heterogeneity in the $1 \mathrm{~km}-2 \mathrm{~km}$ buffer zones.

\section{Landscape Class Level Indexes in Different Buffer Zones}

Statistics of landscape class-level indexes in different buffer zones were shown in Fig. 5. There were relatively few salt pans, construction lands and Spartina alterniflora in buffer zones, which were not listed here. With respect to cPland, there were extensive distributions of seawater and farmland in the $0.5 \mathrm{~km}-1 \mathrm{~km}$ buffer zones. There's an extensive area of tidal flat in the $1 \mathrm{~km}-2.5 \mathrm{~km}$ buffer zone. There were relatively uniform distributions of aquafarm in the five-level buffer zones, which also reflected strong disturbances by human activities. There were few and uneven distributions of dry ponds in the buffer zones at different levels. Phragmites australis landscape had an extensive distribution in the $0.5 \mathrm{~km}$ buffer zone. Suaeda salsa landscape concentrated in the $1.5 \mathrm{~km}$ buffer zone and there's few distribution in the $2.5 \mathrm{~km}$ buffer zone. Maximum, minimum, median, upper quartile and lower quartile of $\mathrm{CPD}$ and $\mathrm{cED}$ showed consistent trends in distribution and variation. The maximums of cPD and cED of seawater, tidal flat, farmland, aquafarm, dry pond and Phragmites australis concentrated within the $0.5 \mathrm{~km}-1 \mathrm{~km}$ buffer zones. In particular, cPD and cED of farmland and aquafarm were far higher than those in other buffer zones. The maximums of cPD and cED of Suaeda salsa concentrate in the $0.5 \mathrm{~km}-2 \mathrm{~km}$ buffer zones, which also indicated the serious landscape fragmentation in this width range of buffer zones. Seawater concentrated in the $1.5 \mathrm{~km}-2.5 \mathrm{~km}$ buffer zones. Tidal flat concentrated in the $0.5 \mathrm{~km}$ buffer zone, and it was more scattered in the $2 \mathrm{~km}-2.5 \mathrm{~km}$ buffer zones. cAI values of farmland and aquafarm showed consistent variation trends. Farmland and aquafarm had a concentrated distribution in the $0.5 \mathrm{~km}-1 \mathrm{~km}$ buffer zones. However, landscape structure in other buffer zones tended to be unstable. Dry pond concentrates in the $0.5 \mathrm{~km}$ buffer zone, but it was relatively scattered in the $1 \mathrm{~km}-2 \mathrm{~km}$ buffer zones. Plaques in the $2.5 \mathrm{~km}$ buffer zone scatter around. Concentration characteristics of Phragmites australis in the $0.5 \mathrm{~km}-2 \mathrm{~km}$ buffer zones are similar. Phragmites australis showed moderate concentration, but the concentration degree in the $2.5 \mathrm{~km}$ buffer zone increased. Suaeda salsa showed relatively low cCOHESION, but high cCOHESION in the $0.5 \mathrm{~km}$ and $1.5 \mathrm{~km}-2.5 \mathrm{~km}$ buffer zones.

\section{Correlation Analysis between Spatial Landscape Pattern and Surface Water Quality}

Analyzing RDA may deepen the understanding correlation and interpretation capacity of regional landscape indexes to environmental chemical indexes [44]. According to the RDA sequence diagram of different buffer zones (Fig. 6), the spatial landscape patterns were expressed by red arrows, while WQ indexes are expressed in black arrows. The Angle between the arrows indicates the size of the correlation. The smaller the Angle, the greater the correlation. When the included Angle is less than 90 degrees, the relationship between the two is positive correlation; greater than 90 degrees is negative correlation, and equal to 90 degrees, there is no correlation. The length of the arrow indicates the size of the relationship between the landscape index and the regional WQ index. The longer the arrow line is, the greater the correlation is; otherwise, the smaller it is.

\section{Correlation between Landscape Type and Surface $W Q$ Indexes}

According to sequence diagrams of landscape type and surface WQ, there were strong correlations among $\mathrm{TN}, \mathrm{TP}$ and $\mathrm{NH}_{4}^{+}-\mathrm{N}$ in different buffer zones. $\mathrm{COD}$ was less correlated with WQ indexes and had independent distributions. In the buffer zone of $0.5 \mathrm{~km}-2.5 \mathrm{~km}$, the total correlation between landscape type and WQ is $0.85,0.718,0.901,0.855$, and 0.849 , respectively.

TN, TP and $\mathrm{NH}_{4}^{+}-\mathrm{N}$ had significantly positively correlations with farmland in the $0.5 \mathrm{~km}, 1 \mathrm{~km}, 2 \mathrm{~km}$ and $2.5 \mathrm{~km}$ buffer zones, but they were significantly negatively correlated with Phragmites australis landscape in the $1.5 \mathrm{~km}$ and $2 \mathrm{~km}$ buffer zones. TN, $\mathrm{TP}$ and $\mathrm{NH}_{4}^{+}-\mathrm{N}$ had significantly negative correlations with the area of tidal flat in all $0.5 \mathrm{~km}-2.5 \mathrm{~km}$ buffer zones. COD was significantly correlated with multiple landscapes in the region. In particular, it was significantly positively correlated with Spartina alterniflora, dry pond and tidal flat, but it had a significantly negative correlation with Phragmites australis.

\section{Correlation between Landscape Level Indexes and Surface WQ Indexes}

Correlation analysis results between landscape level indexes and WQ indexes are shown in Fig. 7. In this study, 11 landscape level indexes and 4 WQ indexes were chosen. The total correlation between landscape level index and water quality from $0.5 \mathrm{~km}$ to $2.5 \mathrm{~km}$ is $0.898,0.701,0.891,0.817$, and 0.858 , respectively. 

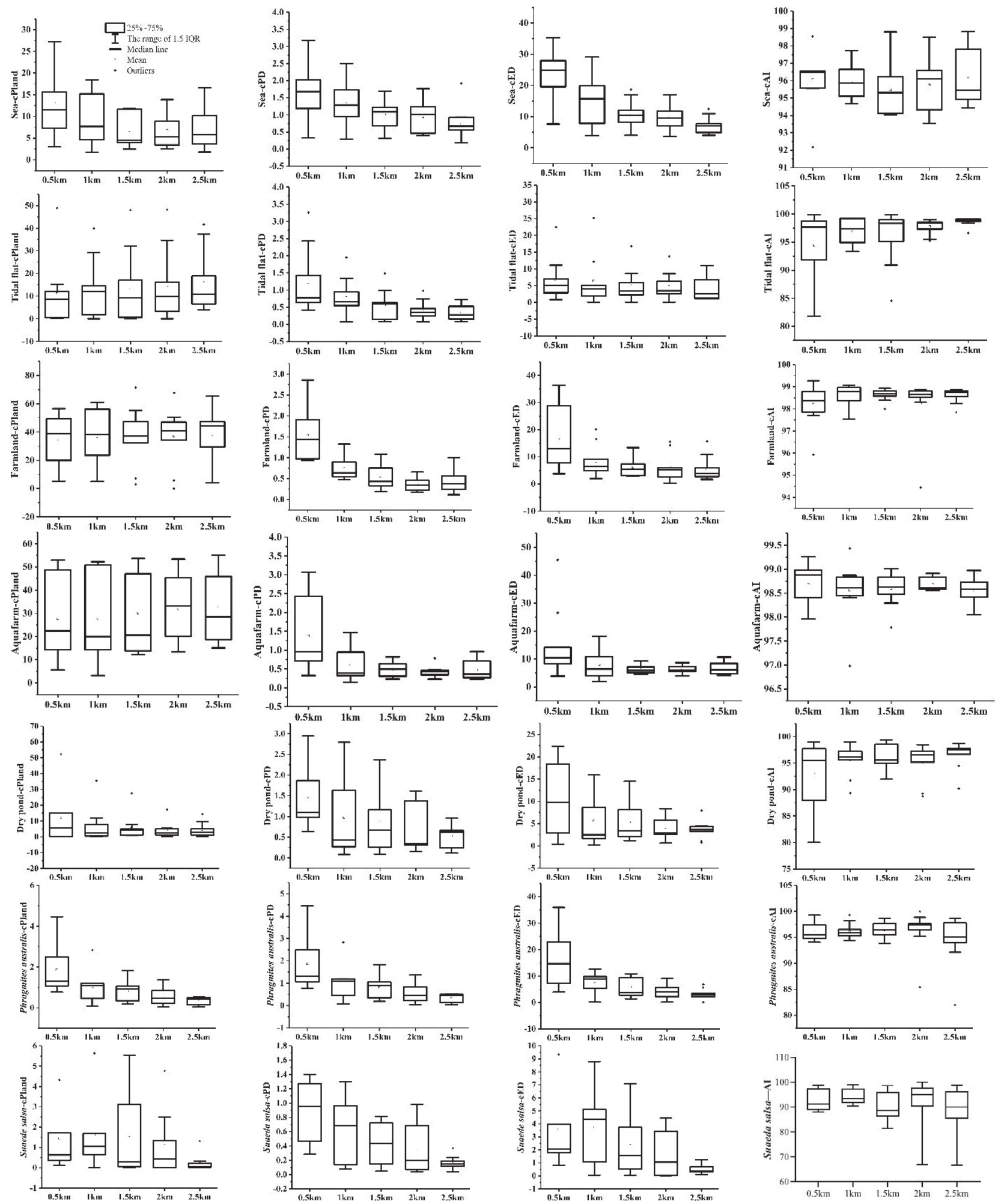

Fig. 5. Statistics of landscape type levels in different buffer zones.

Note: Sea-cPland, Sea-cPD, Sea-cED, and Sea-cAI are the landscape type percentage, patch density, patch edge density, and aggregation index of seawater. Tidal flat-cPland, Tidal flat-cPD, Tidal flat-cED, and Tidal flat-cAI are the landscape type percentage, patch density, patch edge density, and aggregation index of tidal flat. Farmland-cPland, Farmland-cPD, Farmland-cED, and Farmland-cAI are the landscape type percentage, patch density, patch edge density, and aggregation index of farmland. Aquafarm-cPland, Aquafarm-cPD, Aquafarm-cED, and Aquafarm-cAI are the landscape type percentage, patch density, patch edge density, and aggregation index of aquafarm. Dry pool-cPland, Dry pool-cPD, Dry pool-cED, and Dry pool-cAI are the landscape type percentage, patch density, patch edge density, and aggregation index of dry pool. Phragmites australis-cPland, Phragmites australis-cPD, Phragmites australis-cED, and Phragmites australis-cAI are the landscape type percentage, patch density, patch edge density, and aggregation index of Phragmites australis. Suaeda salsa-cPland, Suaeda salsa-cPD, Suaeda salsa-cED, and Suaeda salsa-cAI are the landscape type percentage, patch density, patch edge density, and aggregation index of Suaeda salsa. 


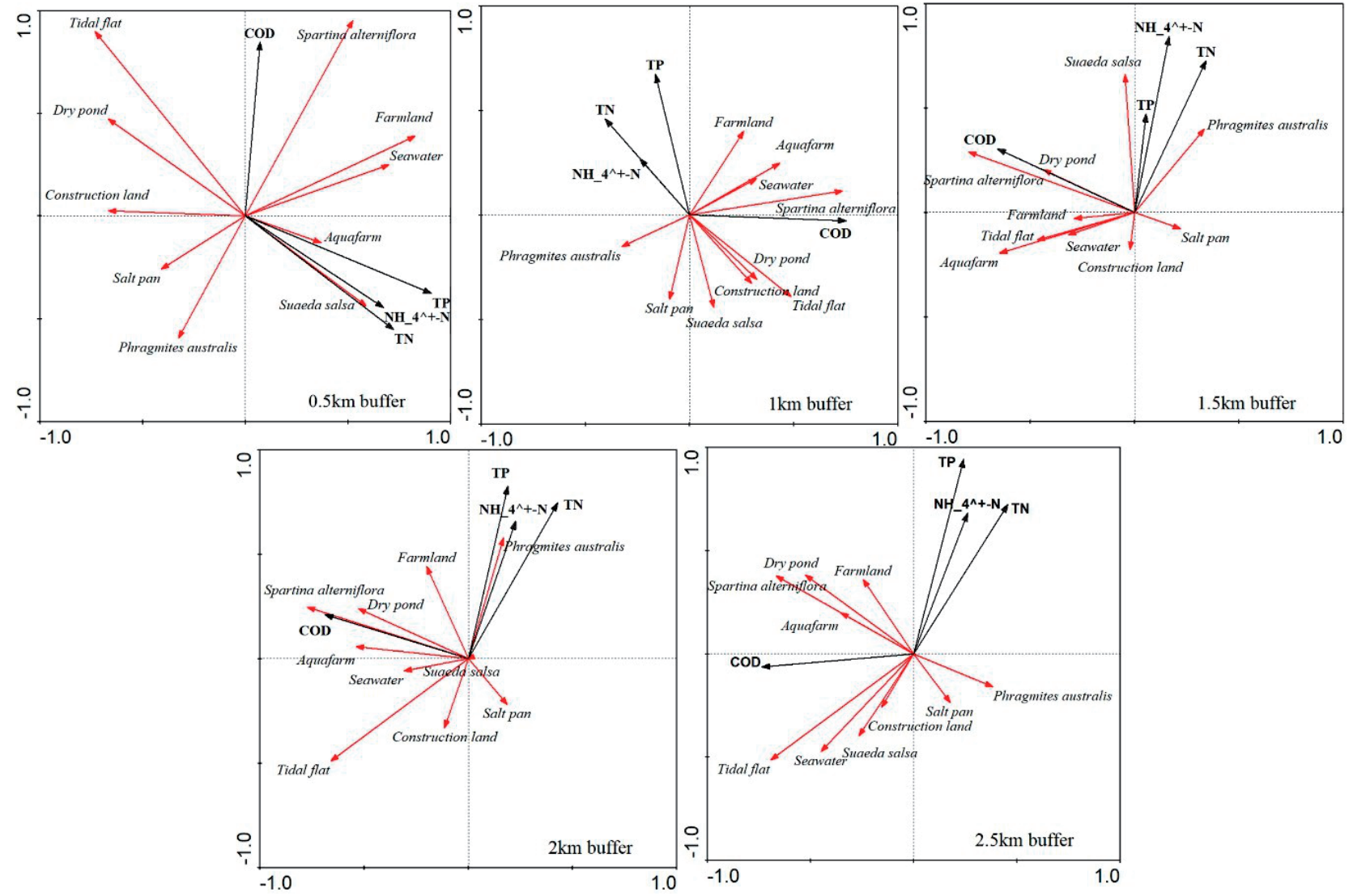

Fig. 6. RDA ranking of landscape types and WQ indicators in different buffer zones.

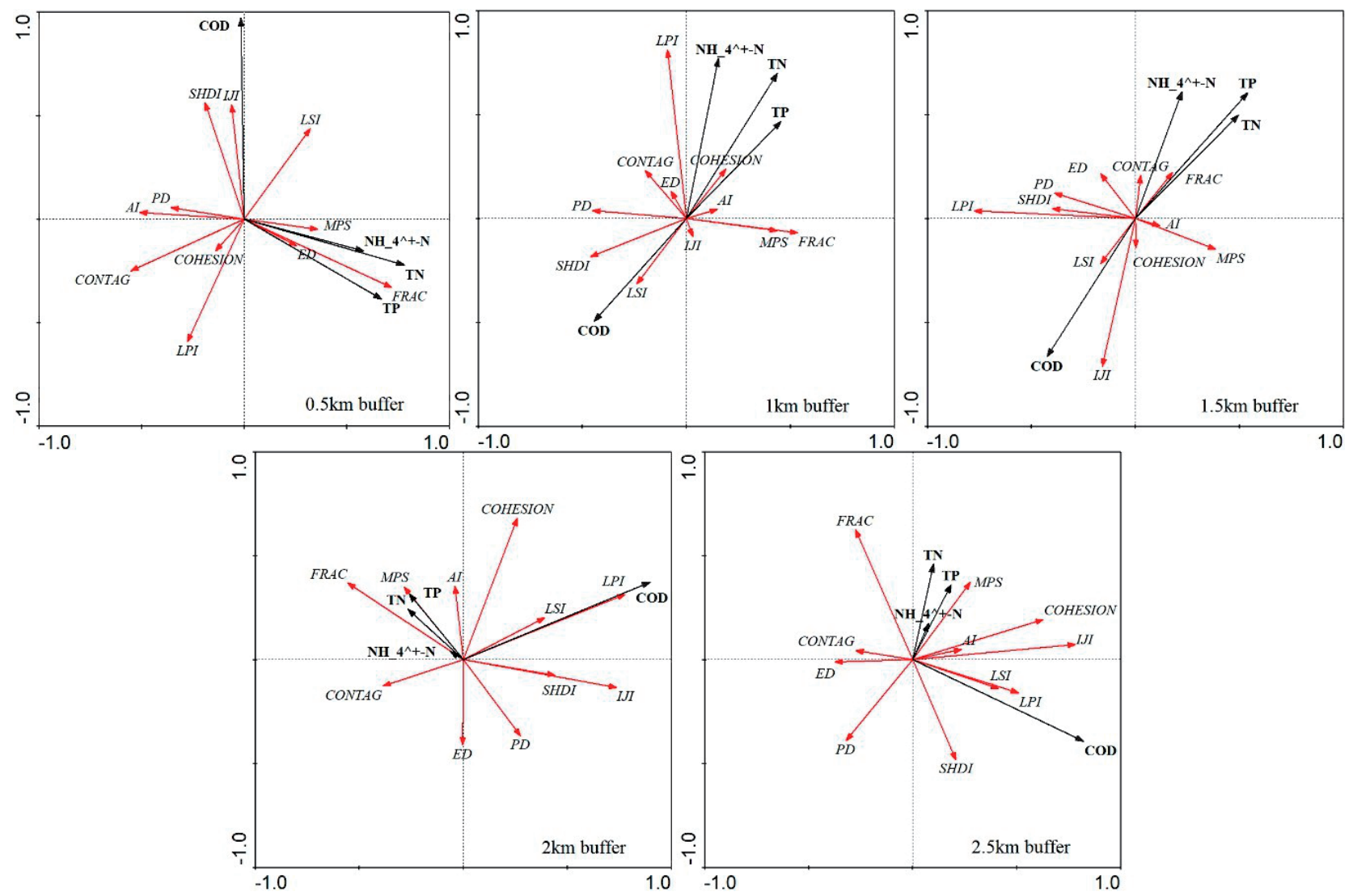

Fig.7. Ranking of landscape level index and WQ index RDA in different buffer zones. 
In the $0.5 \mathrm{~km}$ buffer zone, $\mathrm{TN}, \mathrm{TP}$ and $\mathrm{NH}_{4}^{+}-\mathrm{N}$ were positively correlated with FRAC, ED and MPS, but they were negatively correlated with AI, PD, CONTAG and SHDI. COD was significantly positively correlated with SHDI, IJI and LSI, but it showed significantly negative correlations with LPI, FRAC and MPS. LSI had significantly positive correlations with TN, TP, $\mathrm{NH}_{4}^{+}-\mathrm{N}$ and COD, but CONTAG and LPI were significantly negatively correlated with $\mathrm{TN}, \mathrm{TP}, \mathrm{NH}_{4}^{+}-\mathrm{N}$ and COD. In the $1 \mathrm{~km}$ buffer zone, LPI could interpret TN, TP and $\mathrm{NH}_{4}^{+}-\mathrm{N}$ the best, manifested by the longest arrow and relatively small included angle. Secondly, LPI showed the second strongest correlations with COHESION, ED, AI, CONTAG, FRAC and MPS. COD had strong positive correlations with LSI and SHDI.

In the $1.5 \mathrm{~km}$ buffer zone, $\mathrm{TN}, \mathrm{TP}$ and $\mathrm{NH}_{4}{ }^{+} \mathrm{N}$ were significantly positively correlated with FRAC, CONTAG and MPS, but they were significantly negatively correlated with LPI, IJI, LSI, SHDI and COHESION. IJI had a strong interpretation capacity to COD, manifested by a significantly positive correlation. COD showed the second strongest positive correlations with LPI, LSI, SHDI and COHESION. In the $2 \mathrm{~km}$ buffer zone, $\mathrm{TN}, \mathrm{TP}$ and $\mathrm{NH}_{4}{ }^{+}-\mathrm{N}$ were significantly positively correlated with FRAC, CONTAG, MPS and AI. COD was positively correlated with LPI, IJI, LSI, SHDI, COHESION and AI. All four WQ indexes showed significantly positive correlations with COHESION, AI and LSI. In the $2.5 \mathrm{~km}$ buffer zone, $\mathrm{TN}, \mathrm{TP}$ and $\mathrm{NH}_{4}^{+}-\mathrm{N}$ were significantly positively correlated with FRAC, CONTAG, MPS, AI and IJI. COD was positively correlated with LPI, IJI, LSI, SHDI, COHESION and AI. All four WQ indexes showed significantly positive correlations with COHESION, AI and IJI.

\section{Correlation between Landscape Class-Level Indexes and Surface $W Q$ Indexes}

Correlations between landscape class-level indexes and surface WQ indexes were analyzed to disclose the interpretation capacity of landscape class-level indexes to surface WQ. Although there are many wetland classes in the study area, this study mainly focused on natural and artificial wetlands.

With respect to artificial wetland (Fig. 8), correlations of farmland, aquafarm, dry pond and

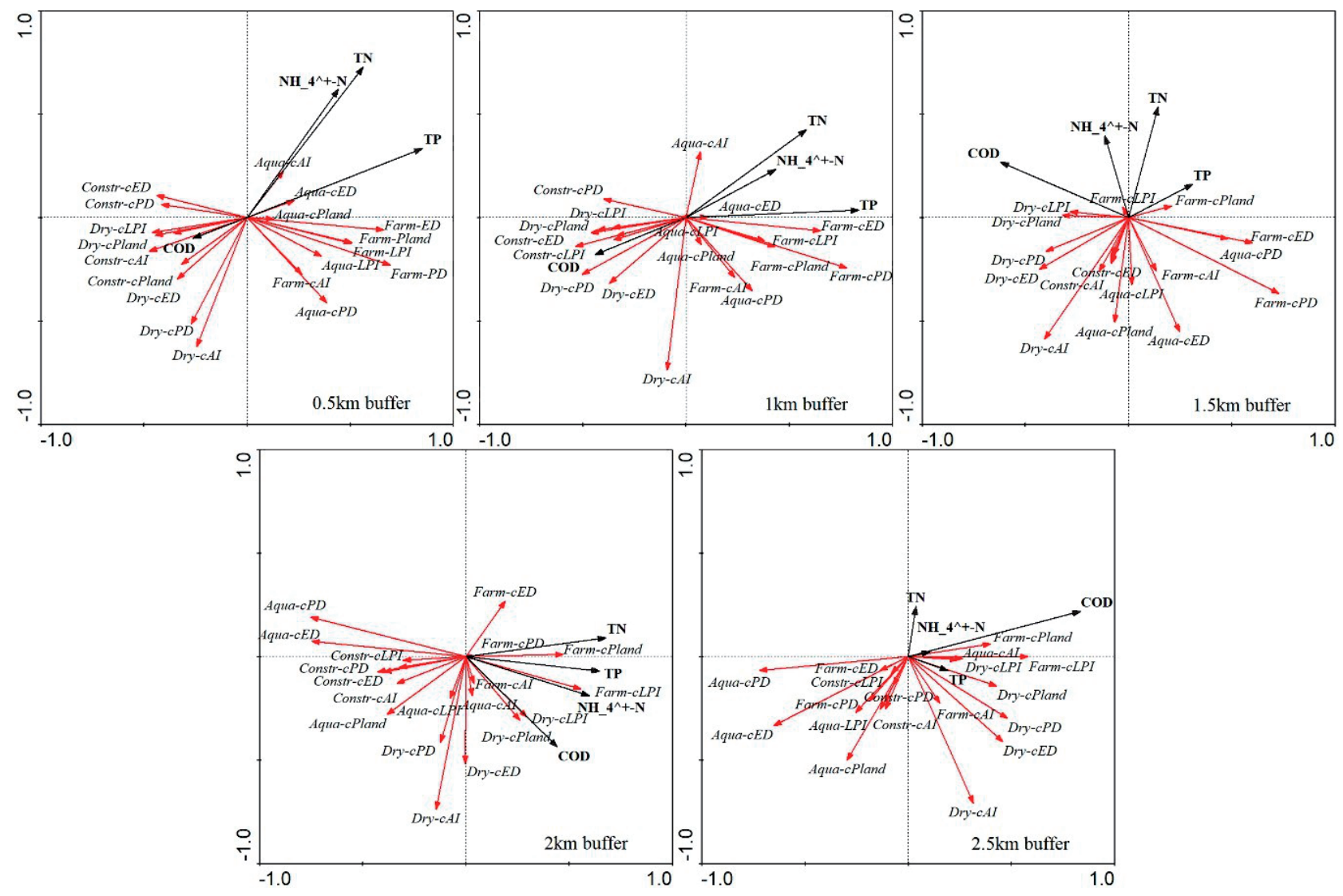

Fig. 8. Ranking of artificial wetland landscape index and WQ index RDA in different buffer zones.

Note: Aqua-cPland, Farm-cPland, Dry-cPland, and Constr-cPland are the landscape type percentage of aquafarm, farmland, dry pond and construction land. Aqua-cPD, Farm-cPD, Dry-cPD, and Constr-cPD are the patch density of aquafarm, farmland, dry pond and construction land. Aqua-cLPI, Farm-cLPI, Dry-cLPI, and Constr-cLPI are the largest patch index of aquafarm, farmland, dry pond and construction land. Aqua-cED, Farm-cED, Dry-cED, and Constr-cED are the patch edge density of aquafarm, farmland, dry pond and construction land. Aqua-cAI, Farm-cAI, Dry-cAI, and Constr-cAI are the aggregation index of aquafarm, farmland, dry pond and construction land. 
construction lands with surface WQ were analyzed. Five indexes were chosen in this study, including cPland, cPD, cED, cAI and cLPI. Within the $0.5 \mathrm{~km}$ $2.5 \mathrm{~km}$ buffer zone, the total correlation between the landscape class index of artificial wetland and water quality is $0.665,0.746,0.937,0.802$, and 0.859 , respectively. In the $0.5 \mathrm{~km}$ and $1 \mathrm{~km}$ buffer zones, $\mathrm{TN}$, TP and $\mathrm{NH}_{4}^{+}-\mathrm{N}$ showed strong correlations. In the 1.5 $\mathrm{km}, 2 \mathrm{~km}$ and $2.5 \mathrm{~km}$ buffer zones, TN, TP, $\mathrm{NH}_{4}^{+}-\mathrm{N}$ and COD presented concentrated distributions and high correlations. In the $0.5 \mathrm{~km}$ buffer zone, cAI, cED and cPland of aquafarm as well as cED, cLPI and cPD of farmland had strong interpretation capacities to $\mathrm{TN}$, $\mathrm{TP}, \mathrm{NH}_{4}^{+}-\mathrm{N}$, accompanied with a significantly positive correlation. These demonstrate that fertilizers and baits used in farmland and aquafarm could influence WQ significantly. COD was strongly correlated with cPland, cPD, cED and cAI of construction land, indicating that construction land could promote COD in the region significantly. In the $1 \mathrm{~km}$ buffer zone, TN, TP and $\mathrm{NH}_{4}^{+}-\mathrm{N}$ were significantly positively correlated with cED, cPD and cPland of farmland as well as
cAI of aquafarm. COD was strongly correlated with construction land and dry pond. In the $1.5 \mathrm{~km}$ and $2 \mathrm{~km}$ buffer zones, landscape class-level indexes were closely related with WQ indexes. TN, TP and $\mathrm{NH}_{4}^{+}-\mathrm{N}$ were strongly correlated with farmland (e.g., cPland and cLPI) and aquafarm (e.g., cPD and cED). COD showed significantly positive correlations with indexes of dry pond, such as cPland and cLPI. In the $2.5 \mathrm{~km}$ buffer zone, $\mathrm{TN}, \mathrm{TP}, \mathrm{NH}_{4}^{+}-\mathrm{N}$ and $\mathrm{COD}$ had significantly positive correlations with cPland and cLPI of farmland as well as cAI of aquafarm. All four WQ indexes presented concentrated distributions. In a word, cPland, cPD, cED and cLPI of farmland and cAI of aquafarm had a strong interpretation to $\mathrm{TN}, \mathrm{TP}$ and $\mathrm{NH}_{4}^{+}-\mathrm{N}$. In the $0.5 \mathrm{~km}-1.5 \mathrm{~km}$ buffer zones, all class-level indexes of construction land and dry pond could interpret COD well. In the $2 \mathrm{~km}-2.5 \mathrm{~km}$ buffer zones, dry pond was the best to interpret COD.

Natural wetland types mainly consist of seawater, tidal flat, Phragmites australis, Suaeda salsa and Spartina alterniflora (Fig. 9). In the buffer zone of $0.5 \mathrm{~km}-2.5 \mathrm{~km}$, the total correlation between the natural

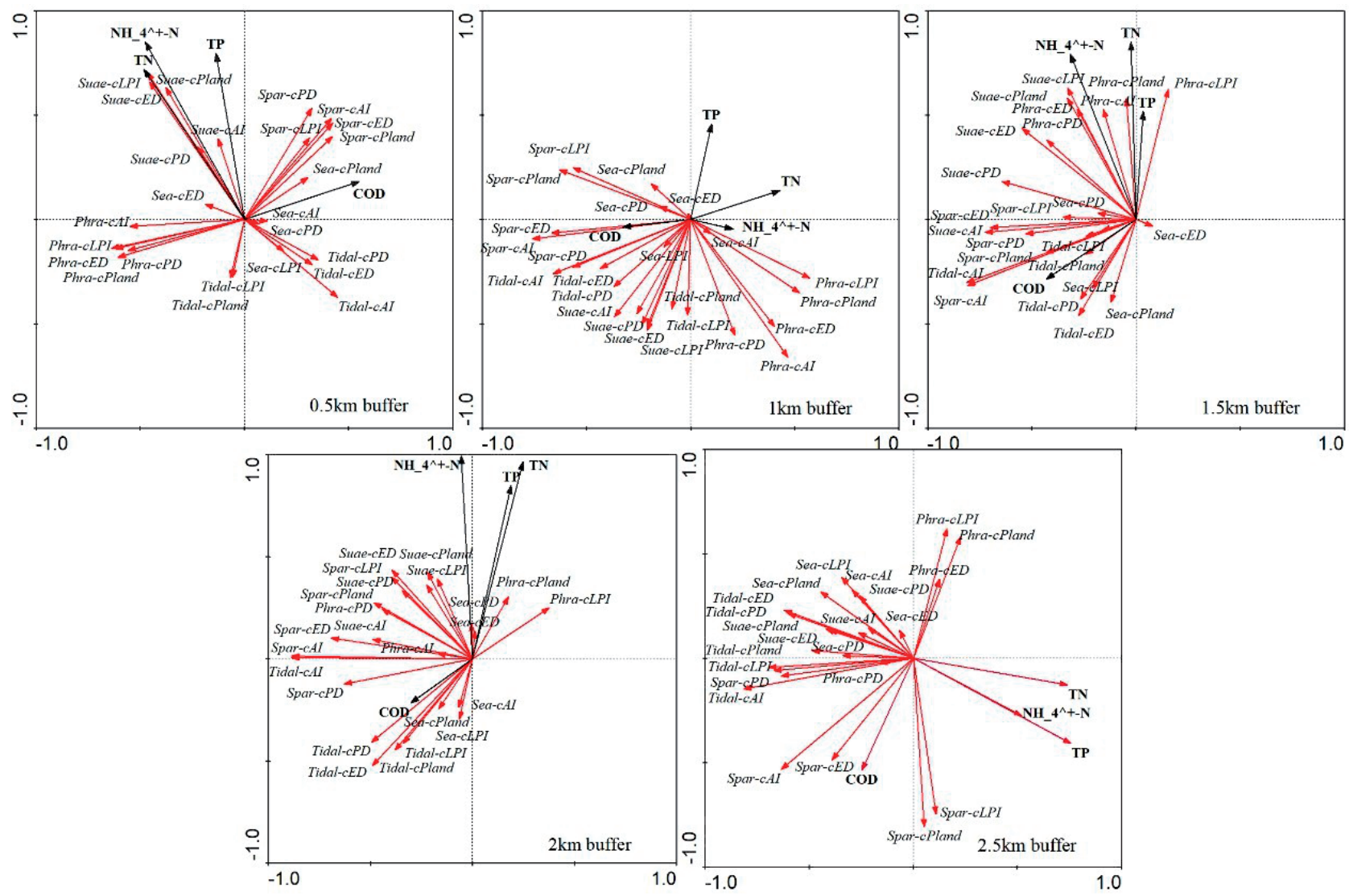

Fig. 9. Ranking of natural wetland landscape index and WQ index RDA in different buffer zones.

Note: Sea-cPland,Tidal-cPland,Phra-cPland,Suae-cPland,and Spar-cPland are the landscape type percentage of seawater, tidal flat, Phragmites australis, Suaeda salsa and Spartina alterniflora. Sea-cPD, Tidal-cPD, Phra-cPD, Suae-cPD, and Spar-cPD are the patch density of seawater, tidal flat, Phragmites australis, Suaeda salsa and Spartina alterniflora. Sea-cLPI, Tidal-cLPI, Phra-cLPI, Suae-cLPI, and Spar-cLPI are the largest patch index of seawater, tidal flat, Phragmites australis, Suaeda salsa and Spartina alterniflora. Sea-cED, Tidal-cED, Phra-cED, Suae-cED, and Spar-cED are the patch edge density of seawater, tidal flat, Phragmites australis, Suaeda salsa and Spartina alterniflora. Sea-cAI, Tidal-cAI, Phra-cAI, Suae-cAI, and Spar-cAI are the aggregation index of seawater, tidal flat, Phragmites australis, Suaeda salsa and Spartina alterniflora. 
wetland landscape class level index and water quality is $0.665,0.89,0.867,0.81,0.907$, respectively. In the $0.5 \mathrm{~km}$ buffer zone, TN, TP and $\mathrm{NH}_{4}^{+}-\mathrm{N}$ presented significantly positive correlations with all five indexes (cPland, cPD, cED, cAI and cLPI) of the Suaeda salsa. COD was positively correlated with five indexes of Spartina alterniflora, cAI, cPD and cED of seawater as well as cLPI, cAI and cPD of tidal flat. In the $1 \mathrm{~km}$ buffer zone, all landscape class-level indexes of Spartina alterniflora and tidal flat had strong interpretation capacities to COD and they showed significantly positive correlations with COD. Three lines of TN, TP and $\mathrm{NH}_{4}^{+}-\mathrm{N}$ were relatively scattered. In particular, $\mathrm{TP}$ was strongly correlated with Pland of seawater. $\mathrm{TN}$ and $\mathrm{NH}_{4}^{+}-\mathrm{N}$ were positively correlated with landscape class-level indexes of Phragmites australis, especially cAI, cPland, cED and cLPI. In the $1.5 \mathrm{~km}$ buffer zone, TN, TP and $\mathrm{NH}_{4}^{+}-\mathrm{N}$ showed significantly positive correlations with landscape indexes of Phragmites australis and Suaeda salsa. COD was closely correlated with landscape indexes of tidal flat and Spartina alterniflora, which was proved by the longest arrow and the smallest included angle of cAI. In the $2 \mathrm{~km}$ buffer zone, landscape indexes of Phragmites australis and Suaeda salsa could interpret TN, TP and $\mathrm{NH}_{4}^{+}-\mathrm{N}$ greatly. cPland, cPD and cED of tidal flat as well as cAI of Spartina alterniflora showed significantly positive correlations with COD. In the $2.5 \mathrm{~km}$ buffer zone, landscape class-level indexes had different correlations with WQ indexes. TN, TP, $\mathrm{NH}_{4}^{+}-\mathrm{N}$ and COD had significantly positive correlations with cPland and cLPI of Spartina alterniflora. Additionally, COD also was closely related with cAI and cED of Spartina alterniflora. In short, TN, TP and $\mathrm{NH}_{4}^{+}-\mathrm{N}$ showed significantly positive correlations with landscape class-level indexes of the Suaeda salsa and Phragmites australis in the $0.5 \mathrm{~km}-2 \mathrm{~km}$ buffer zones. In the $2.5 \mathrm{~km}$ buffer zone, Spartina alterniflora had a strong interpretation capacity to $\mathrm{TN}, \mathrm{TP}, \mathrm{NH}_{4}^{+}-\mathrm{N}$ and COD. Spartina alterniflora could influence COD in different buffer zones significantly.

\section{Discussion}

\section{Impact of LULC-Landscape Types on WQ in Coastal Wetlands}

There is a significant correlation between regional LULC-landscape patterns and water pollutant concentration indicators. In previous studies, urban construction land is the main source of regional water pollution, and it has the greatest ability to explain water pollution [30]. The reason is that urban construction land is the most intense regional patch of human activity. Road hardening makes cities impervious to water. The increase in impervious surface area and the high pollution caused by urban industry and living have deepened the concentration of WQ pollutants in urban areas and become the main source of pollution output in the region. The second major pollution source is cultivated land [15]. Due to the increased use of cultivated land by human activities, a large number of pesticides and chemical fertilizers are applied to farmland, which increases chemical elements in a regional farmland and exacerbates the deposition of pollutants. This study used the Yancheng coastal wetland as a research area. The construction area of coastal wetland was small, while the area of artificial wetland was relatively large. The area of farmland, aquafarm, and dry pond in the $0.5 \mathrm{~km}-2.5 \mathrm{~km}$ buffer zones was larger. Pond farming requires the application of a large amount of fertilizer and the chemical element deposition intensity and rate in this landscape are much greater than other landscape types. For example, TN, TP, $\mathrm{NH}_{4}^{+}-\mathrm{N}$ WQ indicators had significant positive correlations with farmland landscapes in the $0.5 \mathrm{~km}, 1 \mathrm{~km}, 2 \mathrm{~km}$, and $2.5 \mathrm{~km}$ buffer zones, and COD indicators had significant positive correlations with dry pond landscapes.

In addition, forest and grassland had a better purification effect on a regional WQ, showing a significant negative correlation. Forest and grassland had a good ability to maintain soil, absorb and retain water, and digest pollutants. For example, Ewane's research showed that forest landscapes could absorb water quality pollutants and improve water quality by increasing forest coverage [6]. In this study, the coastal wetland, taking the seawater, tidal flat, Phragmites australis, Suaeda salsa and Spartina alterniflora as the typical natural wetlands had a significant impact on the WQ indicators: (1) TN, TP, $\mathrm{NH}_{4}^{+}-\mathrm{N}$ indicators in the buffer zones of $0.5 \mathrm{~km}-2.5 \mathrm{~km}$ had a significantly negative correlation with tidal flat; (2) COD indicators maintained a significant negative correlation with Phragmites australis landscape; and (3) surface runoff carried surface pollution. The WQ pollution of TN, TP and $\mathrm{NH}_{4}^{+}-\mathrm{N}$ in tidal flat was relatively small, and the large area distribution of Phragmites australis played a certain role in purification of WQ pollutants.

\section{Impact of Difference Landscape Indices on WQ Index}

The impact of coastal wetland landscape index on wetland WQ environment is not only reflected in the regional differences of different landscape types, but also affected by the differences of internal structure, function and layout of different landscape types. Taking the cohesion index of this paper as an example, the cohesion index reflects the connection of regional landscape. The higher the connectivity of landscape, the faster the material exchange and capacity transfer, which is more conducive to pollutant treatment and digestion. For example, COHESION index had a strong correlation with WQ pollutants in $1 \mathrm{~km}, 2 \mathrm{~km}$ and $2.5 \mathrm{~km}$ buffer zones. Therefore, at the landscape level, when the regional landscape is connected with a certain type of landscape or with an absolutely large and 
dominant landscape type, the concentration of water pollutants is lower and the WQ conditions are better. The results of this study were also consistent with the results of Wang's [18] study on WQ factors in the Ebinur Lake oasis.

In terms of class level, the landscape type percentage (Pland) and the largest patch index (LPI) reflect the spatial distribution of the dominant landscape types and the largest patch types in the region, and have a more direct impact on the regional WQ. The aggregation of Suaeda salsa, Phragmites australis and Spartina alterniflora in the natural wetland, such as cAI index, helps intercept pollutants and reduce the concentration of pollutants in the whole area, but the concentration of pollutants also increases the concentration of pollutants in the nearby water. In the constructed wetland, farmland, fishpond, construction land and dry pond had their own outstanding boundary scope, and had a great impact on their own scope. If the edge density (ED) is large, it indicates that the more complex the patch shape, the more difficult it is to flow and digest pollutants, which deepen the pollutant concentration in the boundary area. This is similar to the research results of $\mathrm{Yu}$ [35], indicating that patch shape can affect regional hydrological process and WQ.

\section{Measures to Improve WQ in Coastal Wetlands}

Based on the influence of the current landscape patterns on the WQ in the Yancheng coastal wetland and the necessity of controlling coastal wetland pollutants and protecting wetland water environment, we should properly take measures to alleviate regional water pollution, improve wetland soil fertility and maintain the stability of coastal wetland ecosystem. The measures may include (i) controlling the area of aquafarm and dry pond reclamation; (ii) reducing the use of agricultural chemicals and fertilizers and developing agricultural remote sensing technology. The use of agricultural chemical fertilizer in Yancheng was on the whole decreasing trend, the application of chemical fertilizer decreased by $21.31 \%$ from 2010 to 2019 , but the total amount was still large. With the development of science and technology, the combination of agricultural remote sensing technology and machinery has become the main development direction in the field of agriculture, which can save $10 \%$ of fertilizer and $23 \%$ of pesticide by determining the amount of seed, fertilizer and pesticide according to the conditions of land and crops [42]. It can effectively improve the application efficiency of regional pesticide fertilizer, thus reducing the environmental pollution caused by pesticide fertilizer; (iii) strictly following the regulations of Nature Reserve protection, (iv) reducing the external interference of human activities on the coastal wetland; (v) increasing the protection of Phragmites australis, tidal flat and Suaeda salsa natural wetland Protect, and (vi) enlarging the patch area of Phragmites australis, Suaeda salsa and other natural vegetation to prevent regional landscape fragmentation.

\section{Conclusions}

In this study, five-level buffer zones were constructed by centering at 64 water quality sampling points in the Yancheng coastal wetland. Using landscape type data in 2019 and multi-season water quality sampling and measurement data, the correlation between landscape pattern and WQ indexes was analyzed through landscape pattern indexes and RDA method. Some major conclusions could be drawn:

(1) The area of artificial wetlands, such as aquafarm, farmland, and dry ponds in the buffer zone was relatively large. As the buffer zone grows from $0.5 \mathrm{~km}$ to $2.5 \mathrm{~km}$, the area of artificial wetlands tended to increase and the area of natural wetlands tended to decrease. It showed that human activities had a significant impact on coastal wetlands. The landscape level index and type level index in different buffer zones were significantly different.

(2) Coastal wetland landscape types were significantly correlated with WQ indicators and the correlations were different. TN, TP, $\mathrm{NH}_{4}^{+}{ }^{-} \mathrm{N}$ water quality indicators showed significant positive correlations with farmland landscapes in the $0.5 \mathrm{~km}, 1 \mathrm{~km}, 2 \mathrm{~km}$, and $2.5 \mathrm{~km}$ buffer zones, and significant negative correlations with the tidal flats in the $0.5 \mathrm{~km}-2.5 \mathrm{~km}$ buffer zones. The COD index had a significant correlation with various landscapes in the region, especially Spartina alterniflora, dry pond, tidal flat and Phragmites australis landscape types.

(3) From the perspective of coastal wetland landscape level, the area and shape of the patches and the fragmentation of the landscape had a significant impact on the regional WQ. At the landscape class level of coastal wetland, the cPland, cPD, cED, and cLPI indexes of farmland and the cAI index of aquafarm had a strong influence on the TN, TP, and $\mathrm{NH}_{4}^{+}-\mathrm{N}$ indicators, respectively. In the buffer zones of $0.5 \mathrm{~km}-2 \mathrm{~km}, \mathrm{TN}$, TP, $\mathrm{NH}_{4}^{+}-\mathrm{N}$ showed significant positive correlations with the landscape type level indices of Suaeda salsa and Phragmites australis, while in the buffer zone of $2.5 \mathrm{~km}$, Spartina alterniflora had a greater impact on TN, TP, $\mathrm{NH}_{4}^{+}-\mathrm{N}$ and COD. To improve regional water quality conditions, it is necessary to rationally control the scale of farmland and aquafarm, increase the area of natural wetlands. This study only selected four seasonal water quality sampling data in a single year, focusing on the unique and typical coastal wetlands in eastern China. Future research will strengthen long-time series of water quality observation and sampling, so as to enrich the content of coastal wetland water quality and landscape research. 


\section{Acknowledgements}

This research project was funded by NSFC-Zhejiang Joint Fund for the Integration of Industrialization and Informatization (U1609203), Natural Science Foundation of Zhejiang Province (LQ20D010006).

\section{Conflict of Interest}

The authors declare no conflict of interest

\section{References}

1. WIJESIRI B., DEILAMI K., MCGREE J., GOONETILLEKE,A. Use of surrogate indicators for the evaluation of potential health risks due to poor urban water quality: a Bayesian Network approach. Environmental Pollution, 655, 2018.

2. BURGI M., SILBERNAGEL J., WU J., KIENAST F. Linking ecosystem services with landscape history. Landscape Ecology, 30 (1), 11, 2015.

3. DONG H., QIN B. Exploring the link between neighborhood environment and mental wellbeing: A case study in Beijing, China. Landscape and Urban Planning, 71, 2017.

4. WU J., HOBBS R. Key issues and research priorities in landscape ecology: an idiosyncratic synthesis. Landscape ecology, 17 (4), 355, 2002.

5. MAZUR A. Quantity and Quality of Surface and Subsurface Runoff from an Eroded Loess Slope Used for Agricultural Purposes. Water, 10 (9), 2018.

6. EWANE E.B. Assessing land use and landscape factors as determinants of water quality trends in Nyong River basin, Cameroon. Environ Monit Assess, 192, 507, 2020.

7. FASHAE O., AYORINDE H.A., OLUSOLA A.O., OBATERU R.O. Landuse and surface water quality in an emerging urban city. Applied Water Science, 9 (2), 2019.

8. FEZZI C., HARWOOD A.R., LOVETT A.A., BATEMAN I.J. The environmental impact of climate change adaptation on land use and water quality. Nature Climate Change, $\mathbf{5}$ (3), 255, 2015.

9. ASARE F., PALAMULENI L.G., RUHIIGA T.M. Land Use Change Assessment and Water Quality of Ephemeral Ponds for Irrigation in the North West Province, South Africa. International Journal of Environmental Research and Public Health, 15 (6), 2018.

10. HUANG J., ZHAN J., YAN H., WU F., DENG $X$. Evaluation of the Impacts of Land Use on Water Quality: A Case Study in The Chaohu Lake Basin. The Scientific World Journal, 329187, 2013.

11. BATENI F., FAKHERAN S., SOFFIANIAN A. Assessment of land cover changes \& water quality changes in the Zayandehroud River Basin between 1997-2008. Environmental monitoring and assessment, 185 (12), 10511, 2013.

12. ZHANG F., WANG J., WANG X. Recognizing the Relationship between Spatial Patterns in Water Quality and Land-Use/Cover Types: A Case Study of the Jinghe Oasis in Xinjiang, China. Water, 10 (5), 2018.

13. GONZALESINCA C.A., KALLIOLA R., KIRKKALA T., LEPISTO A. Multiscale Landscape Pattern Affecting on Stream Water Quality in Agricultural Watershed, SW Finland. Water Resources Management, 29 (5), 1669, 2015.

14. XIE Y., YU X., NG N.C., LI K., FANG L. Exploring the dynamic correlation of landscape composition and habitat fragmentation with surface water quality in the Shenzhen river and deep bay cross-border watershed, China. Ecological Indicators, 231, 2018.

15. HUBELOVA D., MALA J., KOZUMPLIKOVA A., SCHRIMPELOVA K., HORNOVA H., JANAL P. Influence of Human Activity on Surface Water Quality in Moravian Karst. Polish Journal of Environmental Studies. 29 (5), 3153, 2020.

16. PACHECO F., FERNANDES L.S. Environmental land use conflicts in catchments: A major cause of amplified nitrate in river water. Science of the Total Environment, 548, 173, 2016.

17. LIU Z., YANG H. The Impacts of Spatiotemporal Landscape Changes on Water Quality in Shenzhen, China. International Journal of Environmental Research and Public Health, 15 (5), 2018.

18. WANG X., ZHANG F. Multi-scale analysis of the relationship between landscape patterns and a water quality index (WQI) based on a stepwise linear regression (SLR) and geographically weighted regression (GWR) in the Ebinur Lake oasis. Environ Sci Pollut Res Int. 25 (7), 7033, 2018.

19. WIJESIRI B., DEILAMI K., GOONETILlEKE A. Evaluating the relationship between temporal changes in land use and resulting water quality. Environmental Pollution, 480, 2018.

20. MENESES B., REIS R., VALE M., SARAIVA R. Land use and land cover changes in Zêzere watershed (Portugal) - Water quality implications. Science of the Total Environment, 527-528 (sep.15), 439, 2015.

21. VREYS N., AME M.V., FILIPPI I., CAZENAVE J., VALDES M.E., BISTONI M.D. Effect of Landscape Changes on Water Quality and Health Status of Heptapterus mustelinus (Siluriformes, Heptapteridae). Archives of Environmental Contamination and Toxicology, 76 (3), 453, 2019.

22. LINTERN A., WEBB J.A., RYU D., LIU S., BENDEMICHL U., WATERS D., WESTERN A.W. Key factors influencing differences in stream water quality across space. Wiley Interdisciplinary Reviews: Water, 5 (1), 2018.

23. LIU J., SHEN Z., CHEN L. Assessing how spatial variations of land use pattern affect water quality across a typical urbanized watershed in Beijing, China. Landscape and Urban Planning, 51, 2018.

24. BOSTANMANESHRAD F., PARTANI S., NOORI R., NACHTNEBEL H.P., BERNDTSSON R., ADAMOWSKI, J. Relationship between water quality and macro-scale parameters (land use, erosion, geology, and population density) in the Siminehrood River Basin. Science of The Total Environment, 1588, 2018.

25. XU G., REN X., YANG Z., LONG H., XIAO J. Influence of Landscape Structures on Water Quality at Multiple Temporal and Spatial Scales: A Case Study of Wujiang River Watershed in Guizhou. Water, 11 (1), 2019.

26. LIBEROFF A.L., FLAHERTY S., HUALDE P., ASOREY M.G., FOGEL M.L., PASCUAL M.A. Assessing land use and land cover influence on surface water quality using a parametric weighted distance function. Limnologica, 28, 2019.

27. ZHOU J.J., XIANG J., WANG L.Y., ZHONG G.S., ZHU G.F., WEI W., FENG W., HUANG M.H. Relationship 
between landscape pattern and hydrochemical characteristics of Binggou River Basin in eastern Qilian Mountains. Chinese Journal of Ecology, 38 (12), 3779, 2019.

28. DING J., JIANG Y., LIU Q., HOU Z., LIAO J., FU L., PENG Q. Influences of the land use pattern on water quality in low-order streams of the Dongjiang River basin, China: A multi-scale analysis. Science of The Total Environment, 205, 2016.

29. TERESA CRISTINA TARLÉ PISSARRA, VALERA C.A., RENATA CRISTINA ARAÚJO COSTA, SIQUEIRA H.E., FERNANDO ANTÓNIO LEAL PACHECO A regression model of stream water quality based on interactions between landscape composition and riparian buffer width in small catchments. Water, 11 (9), 1757, 2019.

30. CHEN Q., MEI K., DAHLGREN R.A., WANG T., GONG J., ZHANG M. Impacts of land use and population density on seasonal surface water quality using a modified geographically weighted regression. Science of the Total Environment. 572, 450, 2016

31. JUNIOR R.V., VARANDAS S., FERNANDES L.S., PACHECO F. Groundwater quality in rural watersheds with environmental land use conflicts. Science of the Total Environment, 493, 812, 2014.

32. SUN X.B., LIU H.Y. Effect of Land Use Change on Wetland Landscape Connectivity and 0ptimization Assessment of Connectivity - A Case Study of Wetlands in the Coastal zone of Yancheng, Jiangsu. Journal of Natural Resources, 25 (6), 892, 2010.

33. ZHANG D.F., D.J., CHEN Z.W., MA X.Y. Changes of Coastal Wetlands in Yancheng for 6 Periods since1960s and Their Driving Factors. Wetland Science, 16 (03), 313, 2018.

34. TIAN P., CAO L., LI J., PU R., SHI X., WANG L., LIU R., XU H., TONG C., ZHOU Z. Landscape Grain Effect in
Yancheng Coastal Wetland and Its Response to Landscape Changes. International journal of environmental research and public health, 16 (12), 2225, 2019.

35. YU S., XU Z., WU W., ZUO D. Effect of land use types on stream water quality under seasonal variation and topographic characteristics in the Wei River basin, China. Ecological Indicators, 202, 2016.

36. HAN L.Y., HUANG Z. L., XIAO W.F., TIAN Y.W., ZENG L.D., WU D. Effects of land use and landscape pattern on nitrogen and phosphorus exports in Lanlingxi watershed of the Three Gorges Reservoir area, China. Environmental Science, 35 (3), 1091, 2014.

37. UNCUMUSAOĞLU A.A., MUTLU E. Evaluating Spatial and Temporal Variation in Tuzaklı Pond Water Using Multivariate Statistical Analysis. Polish Journal of Environmental Studies. 28 (5), 3861, 2019.

38. CAO C., ZHANG F., ZHU S.D., GUO M. Relationship between landscape pattern and water quality in the Ebinur lake region. Environmental Science, 39 (4), 1568, 2018.

39. LIU Y.C., LIU Y.X., LI J.L., LU W.Y., WEI X.L., SUN C. Evolution of landscape ecological risk at the optimal scale: a case study of the open coastal wetlands in Jiangsu, China. International journal of environmental research and public health, 15 (8), 1691, 2018.

40. MONICA N., CHOI K.S. Temporal and spatial analysis of water quality in saemangeum watershed using multivariate statistical techniques. Paddy \& Water Environment, 14 (1), 3, 2016.

41. TASDIGHI A., ARABI M., OSMOND D.L. The relationship between land use and vulnerability to nitrogen and phosphorus pollution in an urban watershed. Journal of Environmental Quality, 46 (1), 1137, 2017.

42. HEGAZY I.R., KALOOP M.R. Monitoring urban growth and land use change detection with GIS and remote sensing techniques in Daqahlia governorate Egypt. International journal of sustainable built environment, 4 (1), 117, 2015. 